\title{
Prevalence of Foam Cells and Helper-T cells in Atherosclerotic Plaques of Korean Patients with Carotid Atheroma
}

\author{
Won-Ha Lee ${ }^{*}$, Young-Hyeh $\mathrm{Ko}^{\dagger}$, Dong-Ik Kim ${ }^{\ddagger}$ \\ Byung-Boong Lee ${ }^{\ddagger}$ and Jeong-Euy Park ${ }^{*}$, \\ Centerfor Clinical Research, Samsung Biomedical Research Institute, Sungkyunkwan \\ University School of Medicine, Seoul, Korea. \\ ${ }^{\dagger}$ Department of Diagnostic Pathology, ${ }^{\ddagger}$ Division of Vascular Surgery, and ${ }^{\S}$ Cardiology \\ Division, Samsung Medical Center, Sungkyunkwan University School of \\ Medicine, 50 Ilwon-dong, Kangnam-ku, Seoul 135-710 Korea \\ Backg round : Inflammation and activation of immune cells have important \\ roles in the pathogenes is of atherosclerosis. We analyzed the involvement of var- \\ io us im mune cells in the pathogenes is of atherosclerosis. \\ Methods : We investigated the presence of foam cells, lymphocytes and killer \\ cells in 11 atherosclerotic plaque specimens removed from Korean patients $w$ ho \\ underwent carotid endoarterectomy. Atherosclerotic plaques were analyzed by \\ im $m$ unohistochemistry using monoclonal antibody specific to foam cells (anti- \\ CD68), pan-T cells (anti-CD3), helper-T cells (anti-CD4), cytotoxic T cells (anti- \\ CD8), granular component of killer cells (anti-TIA-1) and pan-B cells (anti- \\ $C D 20$ ). \\ Results: A nalysis revealed a general infiltration of immune cells not only in \\ atheroscle rotic plaques but also in the vascularwalladjacent to the plaque. Heavy \\ infiltration of $\mathrm{CD} 8^{+}$macrophage was observed in all cases. In addition, sig- \\ $n$ if ic ant inf iltration of $C D 3^{+} T$-ly mphocytes $w$ as observed in all cases, while CD2 $0^{+}$ \\ $B$-cells were observed in only a few cases. Majority of the CD ${ }^{+}$cells $w$ as found \\ to be $\mathrm{CD}^{+}$helper-T cells. CD8 ${ }^{+}$cytotoxic $T$ cells and $T I A-1^{+}$cells were less \\ p ro $m$ ine $n t$.
}

Conclusion: Analysis of the human atherosclerotic plaques suggested that helper-T cells and foam cells had a major role in the plaque development.

Key Words: Atherosclerosis; foam cells; T-lymphocytes; CD68;CD4

\section{INTRODUCT ION}

Increasing evidence suggests that inflammatory changes and activation of immune cells are involved in the initial and acute phase of atheroscleros is ${ }^{1)}$. The activation

Address reprint requests to : Jeong-Euy Park, Cardiology Division, Samsung Medical Center, Sungkyunkwan University School of Medicine, 50 Ilwon-Dong, Kangnam-Ku, Seoul 135-710 Korea. of monocytes by agents such as oxidized-low density lipoprote in (oxi- LDL) is believed to initiate atheroscleros is. Subsequent transformation of monocytes to macrophage/ foam cells leads to the formation of the hallmark of atherosclerosis: fatty streak. Foam cells produce various growth factors and extracellular matrix proteins that stimulate the proliferation of vascular smooth muscle cells and lead to the formation of atherosclerotic plaques ${ }^{2}$. Foam cells are involved in not only the intiation but also the acute rupture of plaque and further formation of 
thrombus through the expression of matrix metalloproteinases, stromelysin and tissue factor ${ }^{3-7)}$.

Activation of T-lymphocytes was also observed in atherosclerotic plaque. Hansson et al. de monstrated the presence of T-cells expressing very late activation antigen- 1 (VLA-1) and HLA-DR, which in T cells are synthesized only in an activated state ${ }^{8}$. Furthermore, at least a subfraction of the activated $\mathrm{T}$-cells in the atherosclerotic plaques appears to be specific to oxi $\mathrm{LDL}$, which is a known inducer of foam cell transformation of monocytes ${ }^{9}$. These observations indicate that the presence of activated $\mathrm{T}$-lymphocytes is a result of specific immune response to atherogenic components. Activated T-lymphocytes derived cytokines, such as Interferon $(\mathbb{F N})-\mathrm{Y}$, are also known to induce instability of the plaque ${ }^{6,10-12)}$. Furthermore, it has been reported that T-lymphocytes isolated from unstable angina patients can activate the procoagulating activity of monocytes isolated from normal individual ${ }^{13}$. In contrast, monocytes is olated from unstable angina patients did not have pro-coagulant activities. These results suggest that $\mathrm{T}$-lymphocytes may control the response of monocytes to atherogenic stimuli.

Previous analys is of atherosclerotic lesions indicated that B-cells may play some important roles. B-cells perform many functions with potential relevance to atherogenesis, such as formation of immune complexes, complement- mediated cytotoxicity (CMC) and anti body de pendent cell mediated cytotoxicity (ADCMC). Immune complexes and complements have been identified in atherosclerotic lesions. These B-celt mediated immune responses could contribute to the core of necrotic debris seen in advanced complicated atherosclerotic lesions ${ }^{16,17}$. Components of activated complements are chemotactic for mononuclear cells, can activate monocyte/ macrophages and polymorphonuclear leukocytes, and have profound regulatory effects on both $\mathrm{T}$ and $\mathrm{B}$ lymphocytes $^{18,19)}$.

Although lots of researchers reported the presence of macrophages, $\mathrm{T}$ cells and $\mathrm{B}$ cells in atherosclerotic plaque, none of them integrated the results in a single setting. We investigated the distribution of foam cells, helper- $\mathrm{T}$ cells, cytotoxic- $\mathrm{T}$ cells, killer cells and B cells in the atherosclerotic plaques removed from patients during the carotid endoarterectomy. Results indicated that foam cells and helper- $\mathrm{T}$ cells constitute a major population of immune cells in the atherosclerotic plaques.

\section{MATERIALS AND METHODS}

1. Patient selection and sample preparation.

We selected 11 patients, aged from 63 to 81 , who underwent carotid endoarterectomy at Samsung Seoul Hospital. The demographic and clinical features of the study subjects are shown in Table 1. Atherosclerotic plaques were washed with saline and fixed with $4 \%$ paraformaldehyde within $1 \mathrm{hr}$ after removal.

Table 1. Characteristics of the study subjects.

\begin{tabular}{lc}
\hline Parameter & value \\
\hline $\mathrm{n}$ & 11 \\
Age (yrs) & $70.5 \pm 9.9$ \\
Sex (male/female) & $11 / 0$ \\
BMI $\left(\mathrm{kg} / \mathrm{m}^{2}\right)$ & $23.1 \pm 3.0$ \\
Total Cholesterol (mg/dL) & $182.0 \pm 30.8$ \\
Smoking (current/ex/non- smoker) & $3 / 3 / 2^{*}$ \\
Hypertens ion (n) & 8 \\
Diabetes Mellitus (n) & 5 \\
\hline
\end{tabular}

Data on age, BMI and total cholesterol are expressed as mean $+\mathrm{SD}$.

* Information for smoking status is not available for 3 patients

\section{Histological analys is.}

Standard 5- $\mu \mathrm{m}$ sections of the tissues were made after the fixation in $4 \%$ paraformaldehyde, dehydration and paraffin embedding. The sections were stained with haematoxylin and eosin. Immunohistochemistry was performed using the LSAB kit (DAKO, Copenhagen, Denmark) according to the manual provided by the manufacturer. Monoclonal antibodies to CD68 (KP1), CD3 (UCHT1), CD4 (MT3 10), CD8 (DK25), CD20 (L26), and TIA- 1 were purchased from DAKO.

\section{RES ULTS}

Heavy infiltration of mononuclear cells was observed in the carotid specimens in all cases. Most of the infiltrated areas included the shoulder regions of the plaques in most of the cases and fibrous cap regions in some cases. Infiltration was also observed in the arterial walls adjacent to the plaque (data not shown).

CD68 is known to be a cellular marker specifically expressed in human monocyte/macrophages ${ }^{20)}$. In all 

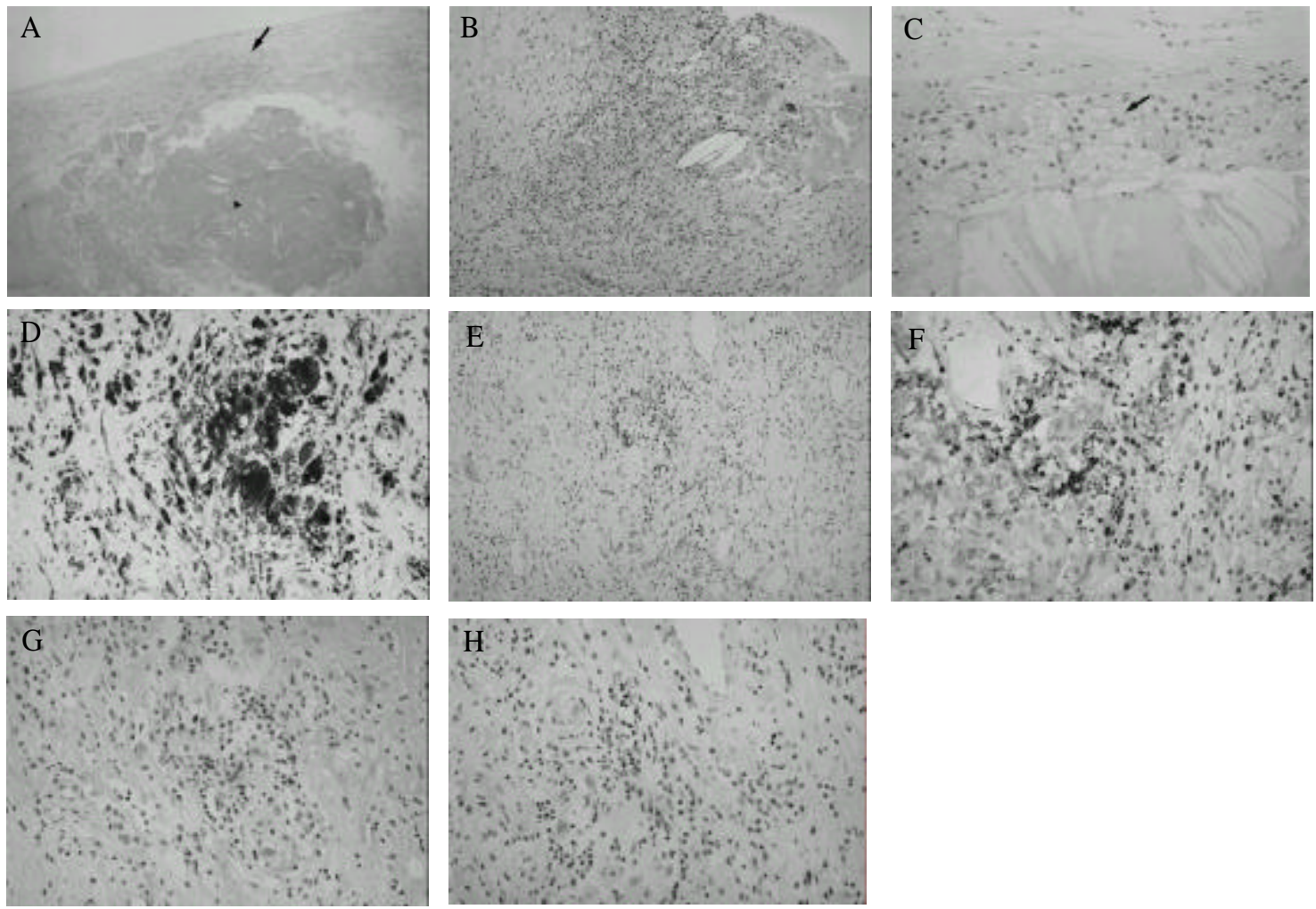

Figure 1. Histological analysis of human athereosclerotic plaques. (A) H\&E staining of atheroscle rotic plaque showing gross morphology. Lipid rich core (triangle) and fibrous cap with focal infiltration of immune cells (arrow) are indicated. (B) H\&E staining of a region of heavy infiltration. (C) H\&E staining showing a foam cell rich region (arrow). Immunohistochemical staining with anti-CD68 (D), anti-CD3 (E), anti-CD4 (F), anti-CD8 (G) and anti-TIA- 1 (H) monoclonal antibodies. Magnification: (A), x40; (B) and (E), x 100; (C), (D), (F), (G), and (H) x200.

cases, heavy staining with anti-CD68 antibody was observed indicating that most of the infiltrating immune cells are in monocyte/macrophage lineage (Table 2 and Figure 1D). The morphological characteristics of these CD68 positive cells indicate that these are foam cells. Most of the CD68 positive foam cells were seen consistently in the intima but were absent from the media and were either isolated or grouped focally.

Various levels of staining, but positive in all cases, were observed with anti-CD3 antibody suggesting that infiltration of T-lymphocytes is involved in the pathogenes is of atherosclerosis (Table 2 and Figure 1E). To find out whether these cells are helper- $\mathrm{T}$ cells or cytotoxic- $\mathrm{T}$ cells, sections were stained with either anti-CD4, which recognizes the helper- $\mathrm{T}$ cells, or an anti-CD8, which recognizes the cytotoxic- $T$ cells. Results indicated that most of the CD3 positive cells are helper- $T$ cells, while cytotoxic- $\mathrm{T}$ cells are less prominent and less frequent (Figure $1 \mathrm{~F}$ and $1 \mathrm{G}$ ). Most of the CD3 and CD4 positive cells were found in areas where most of the foam cells were found.

Staining with anti-TIA- 1 antibody (Figure 1H), which binds the serine esterase-positive granule membrane components of cytotoxic T-lymphocytes and natural killer cells $^{21,22)}$, also resulted in low incidences (Table 2 and Figure $1 \mathrm{H}$ ). Staining for a pan- B cell marker, CD20, revealed that positive staining was observed only in 3 out of 11 cases (Table 2).

\section{DIS CUS S ION}

The most important observation made in this study is that all of the carotid atherosclerotic plaques are heavily infiltrated with foam cells and helper- $\mathrm{T}$ cells. This 
W.H. LEE, Y.H. KO, D.I. KIM, B.B. LEE, J,E, PARK

Table 2. Summary of immunophenotypic analys is of infiltrating inflammatory cells in athe roscle rotic plaque

\begin{tabular}{|c|c|c|c|c|c|c|}
\hline Patient No. & CD3 & CD4 & CD8 & CD20 & CD68 & TIA- 1 \\
\hline $\mathrm{P} 1$ & $+1+$ & + & ++ & - & $+1++$ & + \\
\hline P2 & + & ++ & + & + & +H+ & H \\
\hline P3 & + & ++ & ++ & $-1+$ & +H+ & $H-$ \\
\hline P4 & H & + & + & - & +1++ & + \\
\hline P5 & +H & H+ & ++ & - & $+1++$ & + \\
\hline P6 & + & ++ & - & + & +++ & $H-$ \\
\hline P7 & + & + & - & + & +++ & + \\
\hline P8 & + & H+ & $H-$ & - & ++ & - \\
\hline P9 & +H & ++ & + & + & +H+ & H- \\
\hline P 10 & + & ++ & + & - & +1++ & - \\
\hline P 11 & +++ & ++ & ++ & - & +1++ & + \\
\hline
\end{tabular}

indicates that helper- $\mathrm{T}$ cells as well as foam cells may play important roles in the formation of plaques. In contrast, other types of cells, such as B cells and cytotoxic- $T$ cells, are not likely to be involved in atherosclerotic plaque formation. Our study, however, does not provide any evidence that the observed $\mathrm{T}$ lymphocytes activate and contribute to lesion progression. We are currently analyzing the activation status of these cells by determining the expression of activation markers.

Development of atherosclerosis proceeds through a complex process involving the deposition of plasma lipoproteins and the proliferation of cellular elements in the artery wall. This chronic condition advances through a series of stages, beginning with fatty streak lesions composed largely of lipid-engorged macrophage foam cells, and ultimately progresses to complex plaques consisting of the core of a lipid and necrotic cell debris covered by fibrous caps. High prevalence of Helper T-cells and monocytes in all atherosclerotic plaques indicate that they either have major roles in the development of plaques or that the development of plaques activate the infiltration of these cells. Several observations suggest that the former is the case. First, monocytes express many cytokines by stimulation with oxidatively modified-LDL. Second, plaques contain oxi-LDL specific T- lymphocytes ${ }^{9}$.

The $\mathrm{CD}^{+}$helper- $\mathrm{T}$ cells observed in this study appear to be associated with monocyte/macrophage lineage cells. Helper- $T$ cells may regulate the attachment and penetration stages of the monocytes. $\mathbf{I}$ is also possible that the T-lymphocytes within the subendothelial intimal space play a significant role in establishing and maintaining the presence of monocyte/macrophage cells in atherosclerotic lesions through the expression of chemotactic factors, such as $\mathbb{L}-8$ and MCP- $1^{25,26)}$. Cytokines secreted by activated $\mathrm{T}$ cells can activate macrophages and regulate their lipoprote in uptake. Activated macrophages, in turn, can secrete a wide variety of potentially atherogenic agents.

Helper- $\mathrm{T}$ cells play an important role in a wide variety of human diseases. I is likely that the helper- $T$ cells within the subendothelial intimal space have the potential ability to directly modify the functions of neighboring endothelial cells, monocyte/macrophages and SMCs, rather than being mere passive onlookers. The possible interaction between these cell types may mediate in many pro-atherogenic events.

\section{ACKNOWLEDGEMENT}

This work was supported by grants from Samsung (C-98-004) and 1998 National R\&D program, MOST, ROK (\#98- N1-02-02-A-05).

\section{REFERENCES}

1. Azar RR, Waters DD. The inflammatory etiology of unstable angina [editorial]. Am Heart J 132:1101-1106, 1996

2. Ross R. The pathogenesis of atherosclerosis: a perspective for the 1990s. Nature 362:801-809, 1993

3. Libby P, Geng YJ, Aikawa M, Schoenbeck U, Mach F, Clinton SK, Sukhova GK, Lee RT. Macrophages and atherosclerotic plaque stability. Curr Opin Lipidol 7: 330-335, 1996

4. Shah PK, Falk E, Badimon JJ, Fernandez-Ortż A, Ma ilhac A, Villa reat Levy G, Fallon JT, Regnstrom J, Fuster V. Human monocyte-derived macrophages induce collagen breakdown in fibrous caps of atherosclerotic plaques. Potential role of matrix-degrading metallop roteinases and implications for plaque rupture. Circulation 


\section{PRE VALENCE OF FOAM CELLS AND HELPER-T CELLS IN ATHEROSCLEROTIC PLAQUES OF KOREAN PATIENTS WTH CAROTID A THEROMA}

\section{$2: 1565-1569, \quad 1995$}

5. Galis ZS, Sukhova GK, Kranzhofer R, Clark S, Libby P. Macrophage foam cells from experimental atheroma const itutiveb produce matrix-degrading proteinases. Proc Natl Acad Sci USA $92: 402-406,1995$

6. Libby P, Sukhova G, Lee RT, Galis ZS. Cytokines regulate vascular functions related to stability of the atherosclerotic plaque. J Cardiovasc Phamacol 25: S9- 2, 1995

7. Mach F, Schonbeck U, Bonnefoy JY, Pober JS, Libby P. Activation of monocyte/macrophage functions related to acute atheroma complication by ligation of CD40: induction of collagenase, stromebsin and tissue factor. Circulation 96:396-399, 1997

8. Hansson GK, Holm J, Jonasson L. Detection of activated T-bymphocytes in the human atherosclerotic plaque. Am J Pathol 135:169- 175, 1989

9. Stemme S, Faber B, Holm J, Wiklund O, Witztum JL, Hansson GK. T-bmphocytes from human atherosclerotic plaques recognize oxidized low density lipoprotein. Proc Natl Acad Sci USA 92:3893-3897, 1995

10. Geng YJ, Hansson GK. Interferon-gamma inhibits scavenger receptor expression and foam cell formation in human monocyte-derived macrophages. J Clin Invest 89:13221330, 1992

11. Jonasson L, Hansson GK, Bondjers G, Noe L, Etienne J. Interferon-gamma inhibits lipoprotein lipase in human monocyte-derived macrophages. Biochim Biophys Acta $1053.43-48, \quad 1990$

12. Hansson GK, Jonasson L, Seifert PS, Stemme S. Immune mechanisms in atherosclerosis. Arteriosclerosis 9:567-578, 1989

13. Serneri GG, Abbate R, Gori AM, Attanasio M, Martini F, Giusti B, Dabizzi P, Poggesi L, Modesti PA, Trotta F, et al. Transient intemittent lymphocyte activation is responsible for the instability of angina. Circulation 86:790-797, 1992

14. Hollander W, Colombo MA, Kirkpatrick B, Paddock J. Soluble proteins in the human atherosclerotic plaque. With spectral reference to immunoglobulins, C3-complement component, apha 1-antitrypsin and apha 2-macroglobulin. Atherosclerosis 34:39 1-405, 1979

15. Vlaicu R, Rus HG, Niculescu F, Cristea A. Immunoglo bulins and complement components in human aortic atherosclerotic intima. Atherosclerosis 55:35-50, 1985

16. Perlmann P, Holm G. Cytotoxic effects of bmphoid cells in vitro. Adv Immunol 11:117-93, 1969

17. Cerottini JC, Brunner KT. Cell-mediated cytotoxicity, allog raft rejection and tumor immunity. Adv Immunol 18:67- 132, 1974

18. Weigle WO, Goodman MG, Morgan EL, Hugli TE. Regulation of immune response by components of the complement cascade and their activated fragments. Springer Semin Immunopathol 6:173-194, 1983

19. Muller-Eberhard HJ. Complement. Annu Rev Biochem 44:697-724, 1975

20. Pulford KA, Sipos A, Cordell JL, Stross WP, Mason DY. Distribution of the CD68 macrophage/myeloid associated antigen. Int Immunol 2.973-980, 1990

21. Tenner- Racz K, Racz P, Thome C, Meyer CG, Anderson PJ, Schlossman SF, Letvin NL. Cytotoxic effector cell granules recognized by the monoclonal antibody TIA- 1 are present in CD8+ bymphocytes in bmph nodes of human immunodeficiency virus - 1-infected patients. Am J Pathol 142:1750-1758, 1993

22. Sale GE, Anderson P, Browne M, Myerson D. Evidence of cytotoxic T-cell destruction of epidermal cells in human graft-vs-host disease. Immunohistology with monoclonal antibody TA-1. Arch Pathol Lab Med 116:622-625, 1992

23. Golay JT, Clark EA, Beverley PC. The CD20 (Bp35) antigen is involved in activation of $B$ cells from the GO to the G1 phase of the cell cycle. J Immunol 135:3795-380 1, 1985

24. Barath P, Fishbe in MC, Cao J, Berenson J, Helfant RH, Forrester JS. Detection and localization of tumor necrosis factor in human atheroma. Am J Cardiol 65297-302, 1990

25. Cushing SD, Berliner JA, Valente AJ, Territo MC, Navab M, Parhami F, Gerrity R, Schwartz CJ, Fogelman AM. Minimally modified low density lipoprotein induces monocyte chemotactic protein 1 in human endothelial cells and smooth muscle cells. Proc Natl Acad Sci U S A 87:5 134-5 138, 1990

26. Terkeltaub R, Banka CL, Solan J, Santoro D, Brand K, Curtiss LK. Oxidized LDL induces monocytic cell expression of interleukin-8, a chemokine with T-bmphocyte chemotactic activity. Artenioscler Thromb 14.47-53, 1994 